S. G. Spickott of the Univorsity of Cambridge states that in his experience medical students aro comparatively very hard-working and conscientious, but lack a necessary scepticism. They have been taught to take everything on text-book authority. They havo nover consulted an original paper, nor have they been trained to assess the worth of original contributors. The authoritarian approach to the teaching of medical students is somothing that we must hope to avoid in new approaches to medical training.

Although the roport suggests much new work of a factual type (and it is probable that some, the psychology and statistical techniques, may be too much or too difficult for many undergraduates), it also makes a plea for a more fundamental approach to the principles of scientific method, the planning of experiments, the drawing of inferences, tho divergent and creative in addition to the convergent and analytical in sciontific thinking. 'This scems to be of absolute importance, but it is my opinion, based on four decades of university teaching, that, for one reason or another, only a small proportion of undergraduates achieve this, however well they may succeed with the disjecta membra of thoir university subjects.

W. L. Sumner

\section{CANCER RESEARCH TO-DAY}

\section{Cellular Control Mechanisms and Cancer}

Edited by P. Emmelot and $O$. Mühlbock. (Unio Internationalis Contra Cancrum Conference.) Pp. xi +387. (Amsterdam, London and New York: Elsevier Publishing Company, 1964.) 110s.

International Symposium on Control of Cell Division and the Induction of Cancer

Held at Lima, Peru, and Cali, Colombia. Edited by C. C. Congdon and Pablo Mori-Chavoz. (National Cancer Institute Monograph No. 14.) Pp. viii + 403. (Bethesda, Md.: U.S. Department of Health, Education and Welfare, 1964. Obtainable from U.S. Government Printing Offico, Washington, D.C.). 4.50 dollars.

THERE is something to bo said for arm-chair travel to conforences, though it is no substitute for the real thing. While ono can mako a moro loisuroly study of thes vistas presented, comparing one with another, one is left with the improssion that without the warmth of the sun the third dimension is lacking. Thoso two conforoncos held in the summer of 1963, one in Amsterdam and the othor in South Amorica, oncompassed very similar fields; the central idea in each caso was that cancer involves basically an abnormality of the control of cell division. In the final summary of the Lima Cali conferenco we road, "Vory little is known about gene control of cell division in any matorial", and again, "It is fair to sizy the basic genotics of tho coll division process is unknown to us". The approach used at both conferences was therefore to consider the type of mechanism which has been shown to control other cellular processes and extra. polate to the control of DNA synthesis and nuclear division.

In other ways the two conferences differed. The Amster. dam conferonoo was open, and was attended by some 300 participants, whereas only 50 were invited to tho South American gathering. Perhaps this makes less difference to the recorded procoodings than to tho informal discussions, but I myself was left with the impression that the South American conference had been the more profit. able. This may have arisen partly from the arrangement of papers in the Amsterdam procoedings; although the roador is told that the conference was divided into sessions on particular topics, the papers are not so classified, nor is he told which papers were invited contributions.

$\Lambda$ heavy responsibility at such conferences is borne by the spoaker who draws together the various contributions and presents the conclusions of the meeting. The highlight of tho Amsterdam conforence is the masterly survey by Kaplan, which should certainly be road first. Some of the papors at Amsterdain were concernod with the classical concepts of carcinogonesis, with the role of viruses, and with the differences betwoen normal and cancer cells. Others describod present-day knowledgo on differentiation and growth rogulation in many diverso systems, topics which are so central to tho cancer problem. The third group of papers described the important work done recently on cellular control mechanisms in bacteria. Kaplan considered the relevance of the Jacob and Monod model of control of protein synthesis in bactoria to the dual control of cell replication and differentiation in multi-cellular organisms, and put forward sovoril hypotheses concorning the interference by carcinogenic agents in cell regulation. Whilo some careinogenic agents, such us radiation, are mutagenic and can produco a direct altoration of the genome, he suggested that othors do not apparently proceed beyond the mombrane, and must exert thoir offects indirectly. It was suggestod that thoy may interfere with the ponetration of inducers of differentiation and thus permit uncontrolled growth. These are exciting conjoctures based on the elegant demonstrations of the factors involved in the control of metabolic enzyme synthesis and activity in bacteria. Whethor or not they are truly relovant to the control of proliferation and growth in mammalian colls is a major problem for the future, as is the full role of viruses in carcinogenosis.

In the South American programme less emphasis was placed on the fundamental aspocts of the biology undorlying the problem and more attention was directed to the induction of cancer. The carcinogenic activities of viruses, radiation and chemical substances were each considered in some detail, and there was an interosting session devotod to geographic pathology. The remaining sessions were on stem cell ronowal systerns and the control of cell division; that is, growth regulation at tissue and cellular lovels.

Those interested in the fundamental aspects of cancer research will find much to educate and inspire them in these volumes. As is to bo expectod in a field which cuts across many disciplines, these books will find a place on the research worker's desk not because the articles are uniquo, though some of them may bo, but rathor because those who took part in the conferences attempted to relate the contribution of their own discipline or study to a central theme. Though there is some duplication of ideas, the two symposia aro in many ways complementary. Potentiul purchasors may, however, be deterred by the price of the Amsterdam volume considering that such publications have a limitod usoful life.

\section{A. B. Carrnie}

\section{ORIGIN OF LIFE}

The Origins of Prebiological Systems and of Their Molecular Matrices

Edited by Sidnoy W. Fox. (Proceedings of a Conferences conducted at Wakulla Springs, Florida, on 27-30 Octobor, 1963.) Pp. $\mathrm{xx}+482$. (New York: Academic Press, Inc.; London: Acodomio Press, Ino. (London), Ltd., 1965.) $64 s$.

CHERE could be no possible excuse, let alone justification, for a book like this to bo roviowod by $\mathrm{kn}$ ordinary biologist like me, except to persuade other ordinary biologists, morphologists, embryologists, palaeontologists, geneticists, and taxonomists to overcome their fears and pay attention to what their biochemist colleagues havo boon doing. It is now nearly a hundred years since Darwin wrote, "It is often said that all the conditions for the first production of a living organism are now present, which oould ever havo boon present. But if (and oh! what a big if!) we could conceive in somo warm littlo 